\title{
Schistosomiasis Mansoni in Bananal (State of São Paulo, Brazil). II. Intermediate Hosts
}

\author{
Horacio Manuel Santana Teles/ ${ }^{+}$, Cláudio Santos Ferreira*, Maria Esther de Carvalho**, \\ Valquíria Rosa de Lima, Fabiana Zacharias**
}

\begin{abstract}
Laboratório de Malacologia **Laboratório de Soroepidemiologia, Coordenação dos Laboratórios de Referência e Desenvolvimento Científico, Superintendência de Controle de Endemias, Rua Paula Souza 166, 01027-000 São Paulo, SP, Brasil *Laboratório de

Parasitologia, Instituto de Medicina Tropical, USP, São Paulo, SP, Brasil
\end{abstract}

\begin{abstract}
We conducted monthly snail captures in Bananal, State of São Paulo, Brazil, between March 1998 and February 2001, to identify Schistosoma mansoni vectors, estimate seasonal population changes, and delimit foci. We also evaluated the impact of improvements in city water supply and basic sanitation facilities. We identified 28,651 vector specimens, 28,438 as Biomphalaria tenagophila, 49 of them $(0.2 \%)$ infected with $\mathrm{S}$. mansoni, and 213 as $\mathrm{B}$. straminea, none of the latter infected. Vectors predominated in water bodies having some vegetation along their banks. Neither population density nor local vegetation could be linked to vector infection. We found the first infected snails in 1998 (from March to May). Further captures of infected snails ocurred, without exception, from July to December, when rainfall was least. Irrespective of season, overall temperature ranged from $16.5^{\circ} \mathrm{C}$ to $21^{\circ} \mathrm{C}$; pH values, from 6.0 to 6.8. Neither factor was associated with snail population density. Frequent contact of people with the river result from wading across it, extracting sand from its bottom, fishing, washing animals, etc. Despite a marked reduction in contamination, cercaria shedding persists. Whatever the location along its urban course, contact with river Bananal, particularly of the unprotected skin, entails risks of infection.
\end{abstract}

Keywords: Biomphalaria tenagophila - seasonality - Schistosoma mansoni - transmission - São Paulo - Brazil

The municipality of Bananal is located in the far eastern side of the State of São Paulo (latitude 22 40 '44"S and longitude $44^{\circ} 19^{\prime} 08^{\prime \prime} \mathrm{W}$ ) at an altitude of $560 \mathrm{~m}$. By highway, it is $346 \mathrm{~km}$ distant from São Paulo. It is bounded north, south and east by the municipalities of Resende, Barra Mansa, Rio Claro and Angra dos Reis, State of Rio de Janeiro; and west by the municipalities of Arapeí and São José do Barreiro, State of São Paulo. Its area is estimated at $615 \mathrm{~km}^{2}$. Its climate is tropical, with quite mild temperatures all over the year. Of a population of 15,000 , a little more than 18,000 inhabitants live in the urban area (Seade 1999).

In the course of an investigation on the geographical distribution and the epidemiological significance of Biomphalaria tenagophila (=Australorbis tenagophilus) as a vector of Schistosoma mansoni in the valley of the river Paraíba do Sul, Corrêa et al. (1962) reported the occurence of this species in the municipality of Bananal, which was verified by Piza et al (1972), the authors of the Chart of Planorbids of the State of São Paulo. Concerning the efficiency of $B$. tenagophila as a vector of $S$. mansoni, Paraense and Corrêa (1963) dissipated any remaining doubts about its susceptibility to $S$. mansoni, until then a dabatable point. Piza (1975) recorded the first autochthonous cases of schistosomiasis in Bananal, presumably based on the detection of infected snails in that munici-

${ }^{+}$Corresponding author. Fax: $+55-11-229.8292$. E-mail: horacio@sucen.sp.gov.br

Received 18 June 2002

Accepted 15 August 2002 pality. The program for the control of schistosomiasis then in force required, for a given area to be recognized as a focus of infection, the identification of locally infected snails, a time-consuming process. However, the recurring diagnosis of human cases of schistosomiasis in the following years implied the identification of infected snails in bodies of water of this municipality, which can be inferred from a report on this subject by the Superintendency Control of Endemic Diseases (Superintendência de Controle de Endemias) (Sucen 1982). Presently, as reports of new cases of this infection became so frequent as to characterize a public health problem, Sucen launched a campaign to use all available resources to promote the prophylaxis of schistosomiasis in Bananal. Aimed at gradually decreasing its prevalence, it included an active search for human carriers and their treatment; an improvement of basic sanitation facilities; the use of molluscicides, and involvement of local authorities in the planning, execution and evaluation of all such measures. To analize the evolution of prophylactic action and its impact on the risk of human infection, we examined vector snails captured during the period from March 1998 to February 2000.

\section{MATERIALS AND METHODS}

We divided the bodies of water within the urban area of Bananal into sections, according to the sites where domestic sewage was discharged. A section between two such sites was never longer than $300 \mathrm{~m}$. Thus, should the use of molluscicides become necessary, any damage to the ichthyofauna would be restricted to such site. Snail captures ocurred in ten sections of River Bananal, four of the Lava-Pés stream and one of each of the following streams: Antônio Siqueira, Palha and Laranjeiras, all of them tributaries of the River Bananal. Three further cap- 
ture sections were located, one in River Turvo and three in a ditch known as Vale da Bênção. The 23 selected sites are mapped out in Fig. 1.

A pentagonal iron frame about $250 \mathrm{~cm}^{2}$ in area, holding a wire netting (mesh area $\cong 2 \mathrm{~mm}^{2}$ ), fixed at the end of a long handle, was used to capture snails. The snails were then put into an adequate container and sent to the Malacological Laboratory, for specific identification, which require a careful dissection of the snail genitalia, and a search for $S$. mansoni cercariae after compression of the soft parts of the snails between two glass plates. Niclosamide (Bayluscide ${ }^{\circledR}$ ), diluted as recommended by Sucen (1982), Mcculloug (1992) and Andrews et al. (1993) was sprayed in those sites where snails infected with $S$. mansoni had been identified. Water temperature and $\mathrm{pH}$ were measured upstream from each site. We are indebted to the Water Eletric and Energy Supply Department (DAEE) for the rainfall data.

\section{RESULTS}

River Bananal divides the municipality of Bananal into two sections: the one in the left bank, composed of the quarters Niterói, Laranjeiras and Cerâmica: and Centro, Vila Bom Jardim and Palha on the right bank.

We captured 28,651 specimens of vector snails: 28,438 of them identified as B. tenagophila and 213 as $B$. straminea, the latter found only in a small dam on the Turvo stream, no specimens of which were found infected. Out of 13,006 snails captured in River Bananal (45.7\% of the total) $28(0.2 \%)$ were shedding cercariae. Snail population density in River Bananal, Lavapés stream and Vale da Bênção ditch was about the same; both the planorbid population density and the proportion of infected vectors were highest in Antônio Siqueira stream. Out of 2,908 specimens captured ( $10.2 \%$ of the total), $16(0.5 \%)$ were shedding cercariae. No planorbid snails were found in Niterói stream (section 16); Palha stream (section 6) remained dry for the duration of the study.
Fig. 2 displays data about snail capture, search for cercariae and average monthly rainfall. Figs 3, 4, 5, 6 display the same data associated to individual bodies of water.

The influence of rainfall upon the behavior of $B$. tenagoplila snails was observed, as well as the fact that infected snails are more numerous just before the period of heavy rainfall. Nevertheless, when our investigation began, in 1998, we captured infected snails during a period in which this would not be expected.

Water $\mathrm{pH}$ was situated between 6.5 and 6.9 and water temperature between $14^{\circ} \mathrm{C}$ and $19^{\circ} \mathrm{C}$, irrespective of season and meteorological conditions. However during most of the time, $\mathrm{pH}$ determinations varied around 6.5 and temperature around $17^{\circ} \mathrm{C}$. Further species of Pulmonata snail species found in Bananal were: Drepanotrema cimex, Physa marmorata and Lymnaea columella.

\section{DISCUSSION}

Despite the fact that $B$. straminea occurs besides $B$. tenagophila in Bananal, the latter species did not demonstrably disperse outside the limits of a small, isolated body of water where a small number of individuals were captured. Thus, no involvement of $B$. straminea in the transmission of schistosomiasis in Bananal can be expected. A significant increase in the number of vector snails captured during recent years is a possible indication of a corresponding increase in $B$. tenagophila population density.

Seasonal variations in B. tenagophila population density are observed, the highest values usually coinciding with the dry season, as has been observed in River Bananal and in Lavapés stream. Pinotti et al. (1960) in the State of Pernambuco (Brazil), Baptista et al. (1989) and Baptista and Jurberg (1993) in the State of Rio de Janeiro, observed similar effects of the amount of rainfall. Concerning the shedding of cercariae, it was predominant in Pernambuco (Northeastern Brazil) during the dry season, as observed in Bananal, while the same occurred in Rio de Janeiro dur-

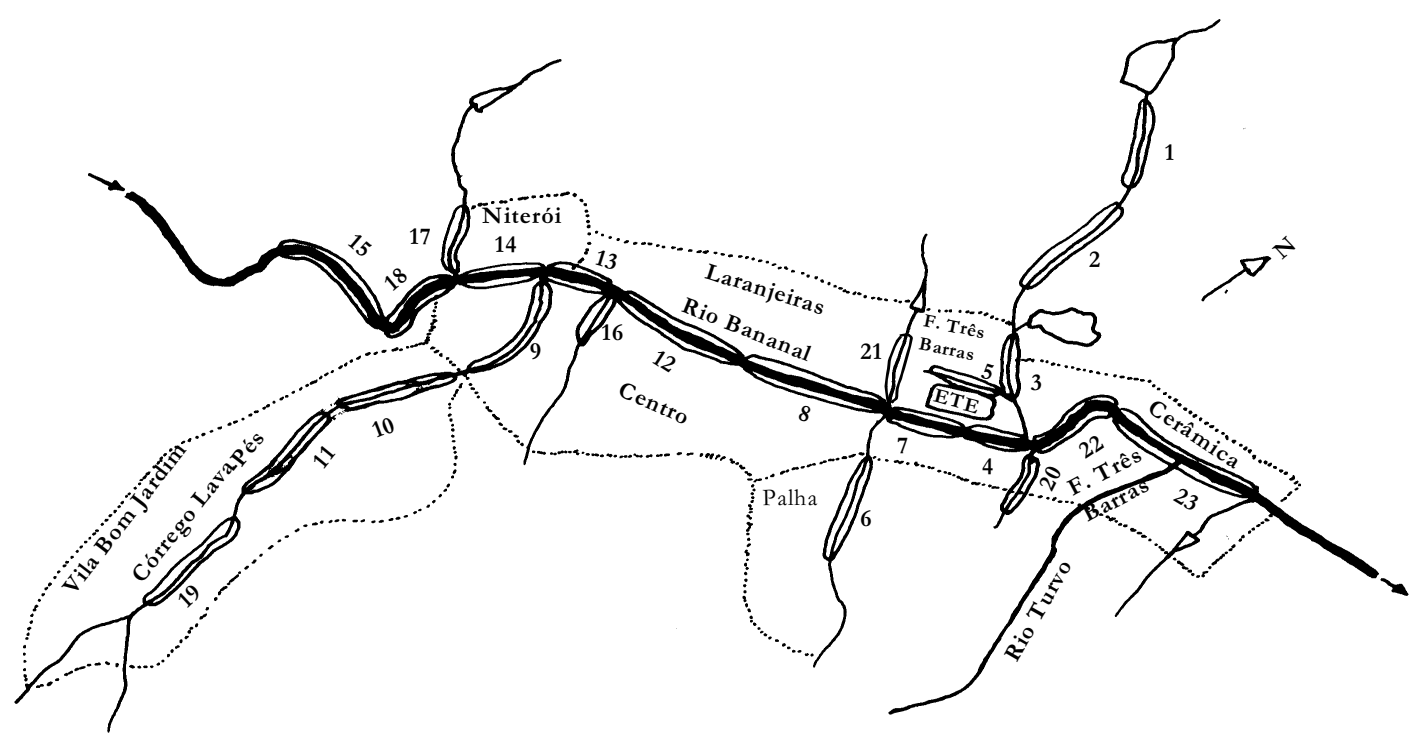

Fig. 1: urban area and snails localities of collects of Bananal, State of São Paulo, Brazil. 
Snails/pluviometry (mm)

$\%$

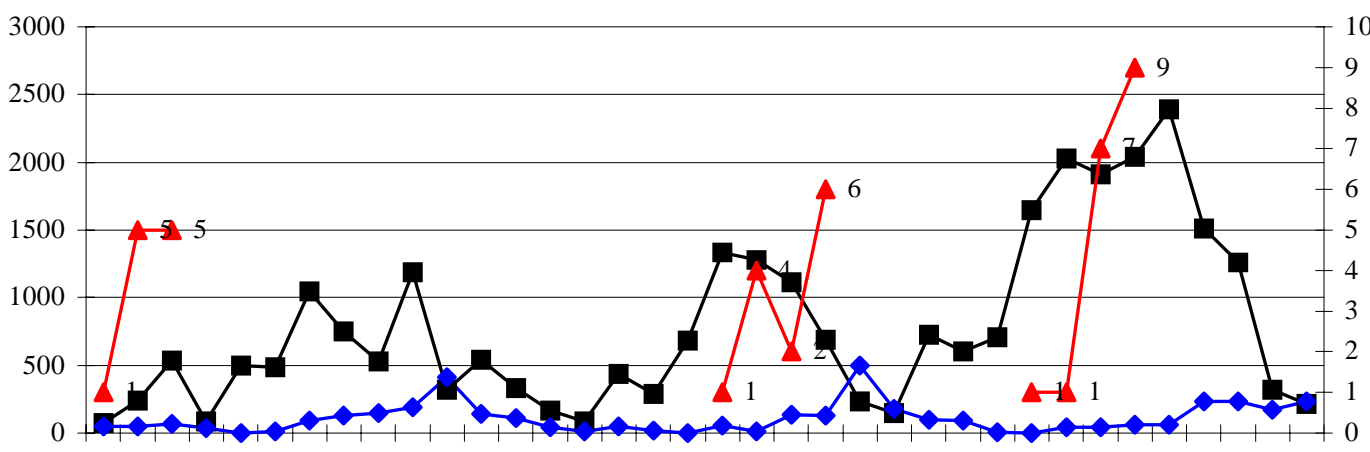

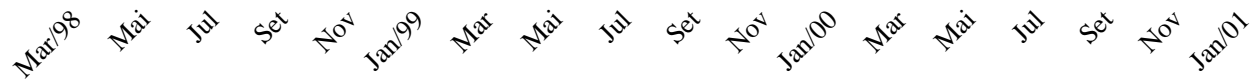

$\rightarrow$ - Snails $\longrightarrow$ Pluviometry $\longrightarrow$ Positives

Fig. 2: snails collected, positives and pluviometry average in the hidric environments of urban area of Bananal, State of São Paulo, Brazil (1998-2001).

Snails/pluviometry

$(\mathrm{mm})$

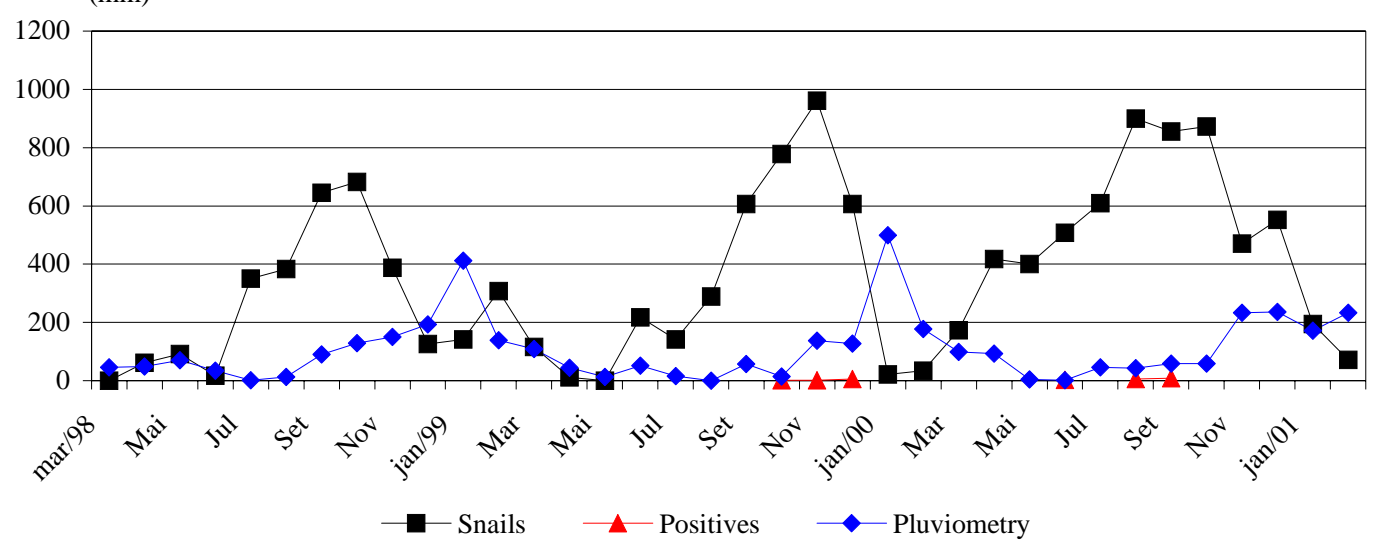

Fig. 3: snails collected, positives and pluviometry average in the Bananal River on urban area of Bananal, State of São Paulo, Brazil (1998-2001).

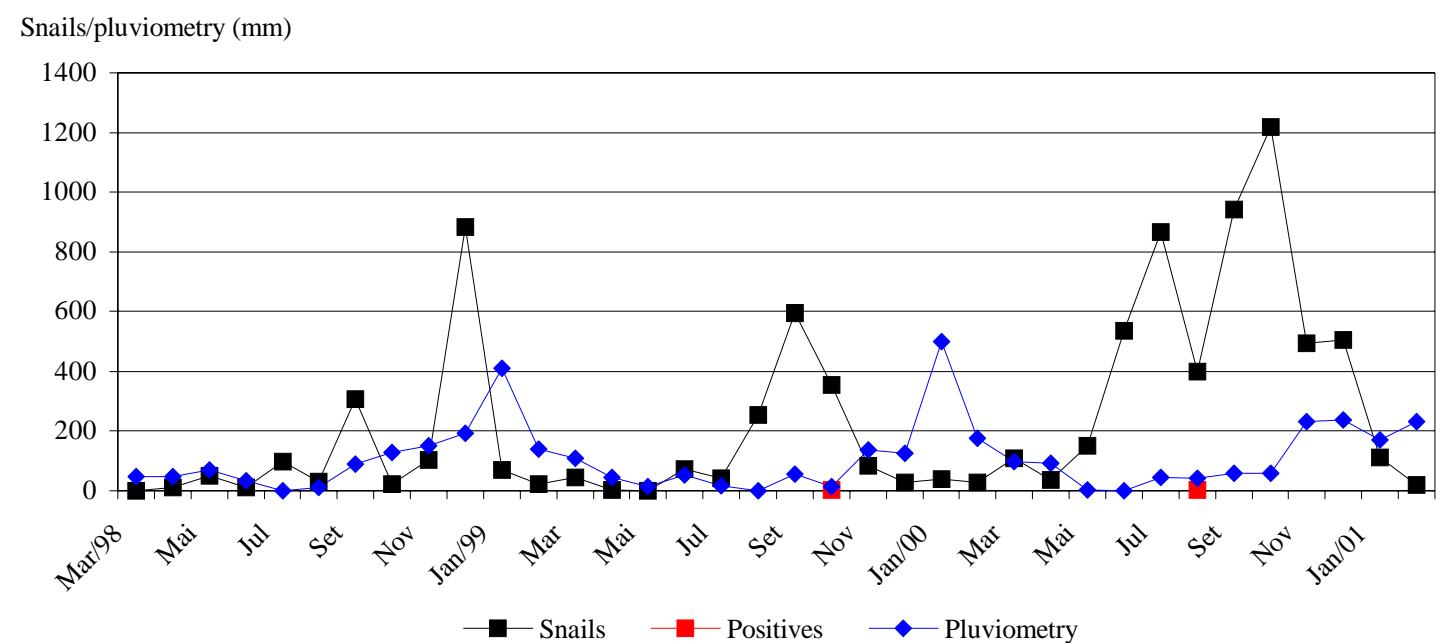

Fig. 4: snails collected, positives and pluviometry average in the Córrego Lava-pés on urban area of Bananal, State of São Paulo, Brazil (1998-2001). 


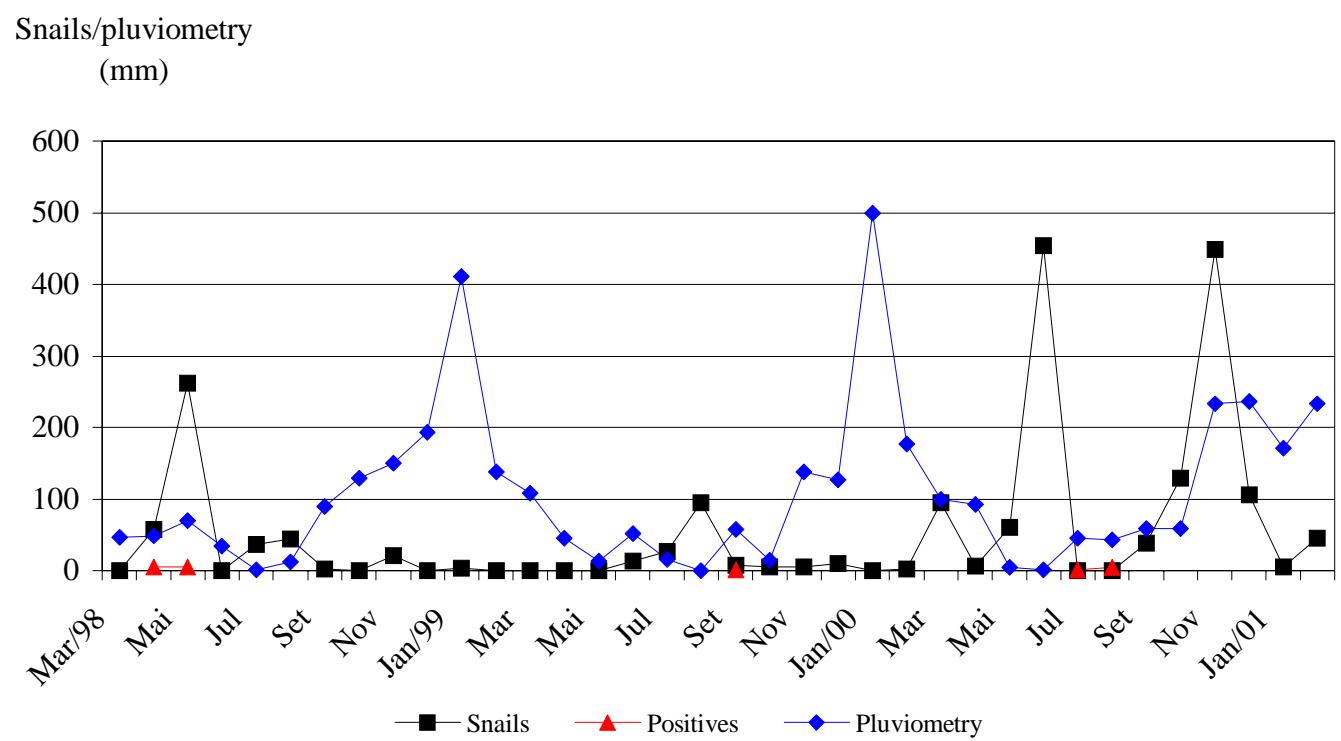

Fig. 5: snails collected, positives and pluviometry average in the Córrego Antônio Siqueira on urban area of Bananal, State of São Paulo, Brazil (1998-2001).

\section{Snails/pluviometry (mm)}

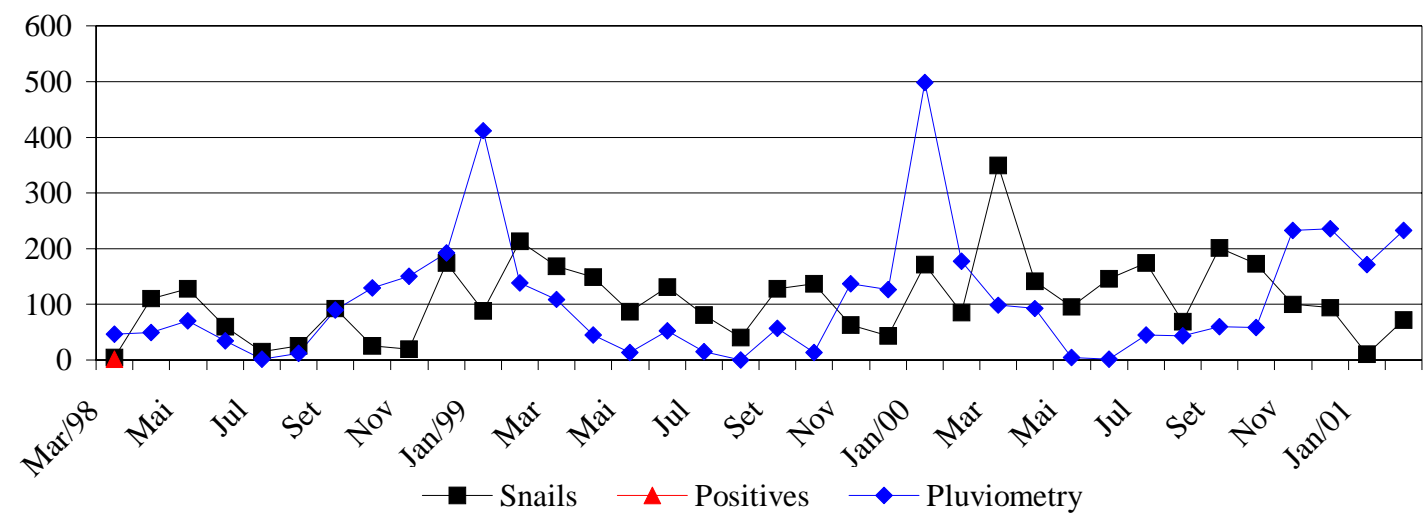

Fig. 6: snails collected, positives and pluviometry average in the Córrego Vale da Benção on urban area of Bananal, State of São Paulo, Brazil (1998-2001).

ing the rainy season. The slight variations in $\mathrm{pH}$ and temperature, observed during this study produced changes in snail population densities and the transmission of the infection, in agreement with the conclusions of Camargo (1977), Baptista et al. (1989) and Baptista and Jurberg (1993). As regards water temperature, Ramos et al. (1961) captured infected B. tenagophila specimens in the Valley of River Ribeira de Iguape during the winter, the water temperature being less than $19^{\circ} \mathrm{C}$ as a consequence of which the snail population density is lowest. Contrariwise, snail population density in Bananal is highest during the winter.

Piza et al. (1960), Piza (1975), Ramos et al. (1961) and Piza and Ramos (1968), observed that high percentages of snails from municipalities inside and outside the valley of the River Paraíba were shedding cercariae. In recent years, Dias et al. (1989) and Marçal Jr. et al. (1991), when examining snails from the municipality of Pedro de Toledo, in the valley of River Ribeira de Iguape, obtained similar results. The percentages of shedding snails were comparable to those recorded by Barbosa and Costa (1961), Baptista et al. (1989), Cutrim and Coura (1992) and Coura Filho et al. (1996) in Northeastern Brazil. A possible reason for the lower percentage figures found in Bananal is the improvement in basic sanitation included in the program for the control of schistosomiasis.

In view of the high complexity of the mechanisms involved in the transmission of schistosomiasis, no simple relationship can be established between the cercaria shedding and human infection, although the former indicates a risk at a given point in time, within certain limits in space. The results of a longitudinal investigation of are useful to 
evaluate fluctuations in the numerosity of the cercaria population, and consequently in the risk of infection. As the density of the cercaria population in a given mass of water varies as a function of time and location, those human activities which involve a prolonged contact with such water are associated with an increased chance of infection. It must be remembered that there are chances of a passive transportation of cercariae to distant places, where no snails can be found, as reported by Machado et al. (1955), Machado and Abreu (1955) and Paraense and Corrêa (1963).

By using molluscicides we could not even momentarily stop the transmission of $S$. mansoni by controlling the density of snail populations or the shedding of cercariae. Although there was a remarkable improvement in the basic sanitation system there was no discontinuity in the identification of snails infected with $S$. mansoni, even in places where the impact of prophilactic measures had been well studied. It must be admitted that the chances of contamination of water bodies with $S$. mansoni eggs from different localities, due to illegal throwing of raw sewage into them is still possible.

It must be emphasized that, since the beginning of the study, annual active search for human carriers of $S$. mansoni and their treatment have been put into action, involving the urban population.

\section{REFERENCES}

Andrews P, Thyssen J, Lorke, D 1993. The biology and toxicology of molluscicide, Bayluscide ${ }^{\circledR}$. Pharmac Ther 19: 245-295.

Baptista DF, Jurberg P 1993. Factors conditioning the habitat and the density of Biomphalaria tenagophila (d'Orbigny, 1835 ) in the isolated schistosomiasis focus in Rio de Janeiro city. Mem Inst Oswaldo Cruz 88: 457-464.

Baptista DF Vasconcelos MC, Schall VT 1989. Study of a population of Biomphalaria tenagophila (Orbigny, 1835) and schistosomiasis transmission in "Alto da Boa Vista", Rio de Janeiro. Mem Inst Oswaldo Cruz 84: 325-332.

Barbosa FS, Costa DF 1961. A long term schistosomiasis control project with molluscicide in a rural area of Brazil. Ann Trop Med Parasitol 75: 45-52.

Camargo S 1977. Controle da densidade de planorbídeos. In Painel Programa Especial de Controle de Esquistossomose, VI Conferência Nacional de Saúde, Ministério da Saúde, Brasília, p. 20-27.

Corrêa RR, Piza JT, Ramos AS, Camargo LV 1962. Planorbídeos do Estado de São Paulo. Sua relação com a esquistossomose (Pulmonata, Planorbidae). Arq Hig Saúde Públ 27: 139-159.

Coura Filho P, Rocha RS, Lamartine SS, Rezende DF, Costa JO, Farah MW, Katz N 1996. Control of schistosomiasis mansoni in Ravena (Sabará, Minas Gerais, Brazil) thougth water supply and quadreannial treatment. Mem Inst
Oswaldo Cruz 91: 659-664.

Cutrim RNM, Coura JR 1992. Schistosomiasis mansoni in three localities of Western Lowland of the State of Maranhão before and after mass treatments. Mem Inst Oswaldo Cruz. 87: $555-558$.

Dias LCS, Kawazoe U, Glasser CM, Shimizu SH, Kanamura HY, Cordeiro JA, Guarita OF, Ishihata GK 1989. Schistosomiasis mansoni in the municipality of Pedro de Toledo (São Paulo, Brazil) where the Biomphalaria tenagophila is the snail host. 1 Prevalence in human population. Rev Inst Med Trop São Paulo 31: 110-118.

Machado PA, Abreu LGS 1955. A ocorrência de furcocercárias em planorbídeos capturados no município de Campinas. Rev Inst Adolfo Lutz 15: 235-240.

Machado PA Guerra JC, Abreu LGS 1955. Planorbídeos no município de Campinas. Rev Inst Adolfo Lutz, 15: 168-172.

Marçal Jr. O, Patucci RMJ, Dias LCS, Hotta LK, Etzel A 1991. Schistosomiasis mansoni in area of low transmission. I. Impact of control measures. Rev Inst Med Trop São Paulo 33: 83-90.

McCulloug FS 1992. The Rule of Mollusciciding in Schistosomiasis Control, World Health Organization, WHO/ SCHISTO/92.107, 34 pp.

Paraense WL, Corrêa LR 1963. Susceptibility of Australorbis tenagophilus to infection with Schistosoma mansoni. Rev Inst Med Trop São Paulo 5: 23-29.

Paraense WL, Corrêa LR 1976. Differential susceptibility of Biomphalaria tenagophila populations to infection with a strain of Schistosoma mansoni. J Parasitol 64: 822-826.

Pinotti M, Rey L, Aragão MB, Cunha AG 1960. Epidemiologia da esquistossomose e variações periódicas das populações malacológicas de Pernambuco, Brasil. Rev Inst Med Trop São Paulo 2: 183-188.

Piza JT 1975. I. Expansão da esquistossomose em São Paulo. II. Medidas adotadas para o seu controle. 28a Reunião Anual da Sociedade Brasileira para o Progresso da Ciência, Brasília (Mimeo.).

Piza JT, Ramos AS 1968. Os focos autóctones de esquistossomose no Estado de São Paulo. Arq Hig Saúde Públ 25: 261-271.

Piza JT, Ramos AS, Brandão CSH, Camargo LSV, Gonçalves JR 1960a. Descoberta de um foco autóctone em Caçapava. Arq Hig Saúde Públ 25: 181-184.

Piza JT, Ramos AS, Moraes LVC, Correa RR, Takaku L, Pinto ACM 1972. Carta Planorbídica do Estado de São Paulo, São Paulo, Secretaria de Estado da Saúde, São Paulo.

Ramos AS, Piza JT, Camargo LSV 1961. Observações sôbre Australorbis tenagophilus, transmissor da esquistossomose mansônica. Arq Hig Saúde Públ 26: 121-124.

Seade 1999. Anuário Estatístico do Estado de São Paulo, Fundação Sistema Estadual de Análise de Dados, São Paulo, $927 \mathrm{pp}$.

Sucen - Superintendência de Controle de Endemias 1982. Situação da Esquistossomose no Estado de São Paulo. Secretaria de Estado da Saúde, São Paulo, 86 pp. 
